\title{
PROBLEMATIKA PENERAPAN MODEL PEMBELAJARAN \\ KOOPERATIF TIPE GROUP INVESTIGATION (GI) \\ DAN ALTERNATIF PEMECAHANANNYA
}

\author{
Octarina Hidayatus Sholikhah
}

Prodi PGSD FIP IKIP PGRI MADIUN

Olla_budi@yahoo.com

\begin{abstract}
In a cooperative learning model, students tasked to construct their own knowledge under the guidance of a teacher who acts as a facilitator and mediator. One model of a cooperative learning is Group Investigation (GI). In its application, found the problem that made the implementation of classroom teaching and learning process is less than optimal. One of the problems that occur are not the evaluation in step group. By reviewing the existing theories and facts that are running in the field, has found a solution to these problems, resulting in improvements in learning steps GI.
\end{abstract}

Key word : Problematics, Group Investigation, Troubleshooting

\begin{abstract}
Abstrak
Dalam model pembelajaran kooperatif, siswa bertugas untuk mengkonstruksikan pengetahuan mereka sendiri dibawah bimbingan guru yang berperan sebagai fasilitator dan mediator. Salah satu model pembelajaran kooperatif adalah Group Investigation (GI). Dalam penerapannya, ditemukan permasalahan yang membuat pelaksanaan proses belajar mengajar di kelas kurang optimal. Salah satu permasalahan yang terjadi adalah belum adanya langkah evaluasi kelompok. Dengan mengkaji teori yang ada dan fakta yang berjalan di lapangan, telah ditemukan solusi dari permasalahan tersebut, sehingga terjadi penyempurnaan dalam langkah-langkah pembelajaran GI.
\end{abstract}

Kata kunci : Problematika, Group Investigation, Pemecahan 



\section{A. Pendahuluan}

Seiring

dengan

perkembangan ilmu pengetahuan dan teknologi yang begitu pesat, maka diperlukan peningkatan Sumber Daya Manusia (SDM) yang mampu mengimbangi melalui pembangunan di bidang pendidikan terutama pendidikan formal. Di dalam pendidikan formal atau sekolah, diharapkan dapat menghasilkan SDM yang berkualitas baik dalam moral, ilmu pengetahuan maupun teknologi, sebab menurut UU RI No.20 tahun 2003 tentang Sistem Pendidikan Nasional, pendidikan nasional bertujuan untuk mengembangkan potensi peserta didik agar menjadi manusia yang beriman dan bertaqwa kepada Tuhan Yang Maha Esa, beraklak mulia, sehat, berilmu, cakap, kreatif, mandiri, dan menjadi warga negara yang demokratis serta bertanggung jawab. Oleh karena itu pendidik berkewajiban merancang dan melaksanakan pembelajaran yang tepat demi meningkatkan prestasi siswa yang mengacu pada peningkatan kualitas SDM.

Matematika mempunyai peranan yang sangat penting dalam kehidupan sehari-hari, sebab matematika banyak diperlukan aplikasinya dalam melaksanakan aktivitas di segala aspek kehidupan, baik pendidikan, ekonomi, sosial maupun aspek yang lain. Berfikir kritis, logis, cermat, sistematis, kreatif dan inovatif merupakan beberapa kemampuan yang dapat ditumbuhkembangkan melalui pendidikan matematika. Oleh karena matematika mempunyai peran yang sangat penting, maka pembelajaran matematika di sekolah harus dapat memberikan bekal pengetahuan bagi siswa serta menghasilkan siswa yang mempunyai kecakapan atau kemampuan matematika.

Fakta yang ada, masih banyak anggapan yang menyatakan matematika sebagai pelajaran yang sulit sehingga sampai saat ini matematika mempunyai nilai yang relatif rendah dibandingkan dengan nilai pelajaran-pelajaran yang lain. Salah satu faktor yang mempengaruhi rendahnya nilai matematika adalah siswa kesulitan dalam memahami materi yang diajarkan. Ada kemungkinan, hal ini disebabkan guru belum mampu memilih model pembelajaran yang tepat dan sesuai dengan tujuan pembelajaran untuk suatu kompetensi tertentu.

Selama ini banyak guru yang masih menggunakan model konvensional, dimana model ini tidak banyak mengikutsertakan keaktifan siswa dalam proses belajar mengajar. Siswa hanya bersikap pasif, sedangkan guru yang bersikap aktif (teacher center). Sehingga diperlukan model pembelajaran yang banyak mengikutsertakan keaktifan siswa (student center) di dalam proses belajar mengajar. Salah satu model pembelajaran yang dapat diterapkan adalah model pembelajaran kooperatif. 
Dalam model pembelajaran kooperatif, siswa bertugas untuk mengkonstruksikan pengetahuan mereka sendiri dibawah bimbingan guru yang berperan sebagai fasilitator dan mediator. Salah satu model pembelajaran kooperatif adalah Group Investigation (GI). Slavin (dalam Rusman, 2012: 221) menjelaskan pengembangan belajar kooperatif GI didasarkan pada suatu premis bahwa proses belajar di sekolah menyangkut kawasan dalam domain sosial dan intelektual, serta proses yang terjadi merupakan penggabungan nilai-nilai kedua domain tersebut. Namun dalam penerapannya, ditemukan permasalahan yang membuat pelaksanaan proses belajar mengajar di kelas kurang optimal. Salah satu permasalahan yang terjadi adalah belum adanya langkah evaluasi kelompok.

\section{B. Pembahasan}

\section{Model Kooperatif}

Model pembelajaran

kooperatif dengan berbagai tipe dikembangkan berlandaskan faham konstruktivisme. Anita Lie (2005: 12) mengemukakan bahwa pembelajaran kooperatif (sistem pembelajaran gotong royong) adalah sistem pembelajaran yang memberikan kesempatan kepada peserta didik untuk bekerjasama dengan sesama peserta didik dalam tugas-tugas yang terstruktur.
Dalam pembelajaran ini guru bertindak sebagai fasilitator.

Slavin (2010: 35) menjelaskan bahwa peserta didik dalam pembelajaran kooperatif akan lebih mudah menemukan dan memahami konsepkonsep yang sulit apabila mereka dapat mendiskusikan konsep-konsep itu dengan teman mereka. Pembelajaran kooperatif mencakup suatu kelompok kecil peserta didik yang bekerja sebagai sebuah tim untuk menyelesaikan sebuah masalah, menyelesaikan suatu tugas atau mengerjakan sesuatu untuk tujuan bersama lainnya. Dalam pembelajaran kooperatif siswa akan terlatih untuk mendengar pendapat-pendapat orang lain dan merangkumnya dalam bentuk tulisan. Tugas-tugas orang lain akan memacu peserta didik untuk bekerja sama, saling membantu dalam mengintegrasikan pengetahuanpengetahuan baru dengan pengetahuan yang dimiliki.

Slavin (dalam Hamdani, 2011: 32) menyatakan terdapat tiga konsep sentral karakteristik pembelajaran kooperatif, sebagai berikut:

1. Penghargaan kelompok

Penghargaan kelompok diperoleh jika kelompok mencapai skor di atas kriteria yang ditentukan. Keberhasilan kelompok didasarkan pada penampilan individu sebagai anggota kelompok dalam menciptakan hubungan antarpersonal yang saling mendukung, membantu, dan peduli.

2. Pertanggungjawaban individu Keberhasilan kelompok bergantung pada pembelajaran individu dari 
semua anggota kelompok. Pertanggungjawaban tersebut menitikberatkan aktivitas anggota kelompok yang saling membantu dalam belajar. Adanya pertanggungjawaban secara individu juga menjadikan setiap anggota siap untuk menghadapi tes dan tugas-tugas lainnya secara mandiri tanpa bantuan teman sekelompoknya.

3. Kesempatan yang sama untuk mencapai keberhasilan

Setiap siswa memberikan kontribusi kepada timnya dengan cara memperbaiki hasil belajarnya sendiri yang terdahulu. Kontribusi semua anggota kelompok dinilai.

Adapun tujuan yang diharapkan dapat dicapai dalam pembelajaran kooperatif, antara lain:

a. Prestasi akademik -

Pembelajaran kooperatif sangat menguntungkan baik bagi siswa berkemampuan tinggi maupun rendah. Khususnya bagi siswa berkemampuan tinggi, secara akademik akan mendapat keuntungan karena pengetahuan semakin mendalam.

b. Penerimaan terhadap keanekaragaman - Heterogen yang ditonjolkan dalam pemilihan anggota kelompok akan mengarahkan siswa untuk mengakui dan menerima perbedaan yang ada antara dirinya dan orang lain.

c. Pengembangan keterampilan sosial Pembelajaran kooperatif bertujuan mengarahkan kepada keterampilan kerjasama sebagai suatu tim. Keterampilan ini kelak akan sangat bermanfaat bagi peserta didik ketika mereka terjun di masyarakat.

Agus Suprijono (2009:

mengungkapkan sintaks pembelajaran kooperatif terdiri dari enam fase, yaitu:

Tabel 1 Sintaks Pembelajaran Kooperatif

\begin{tabular}{ll}
\hline \multicolumn{1}{c}{ Fase-fase } & \multicolumn{1}{c}{ Perilaku Guru } \\
\hline $\begin{array}{l}\text { Fase 1: } \\
\text { Menyampaikan tujuan dan } \\
\text { memotivasi siswa. }\end{array}$ & $\begin{array}{l}\text { Menyampaikan semua tujuan yang ingin dicapai } \\
\text { selama pembelajaran dan memotivasi siswa } \\
\text { untuk belajar. }\end{array}$ \\
\hline $\begin{array}{l}\text { Fase 2: } \\
\text { Menyajikan informasi. }\end{array}$ & $\begin{array}{l}\text { Menyajikan informasi kepada siswa dengan } \\
\text { jalan demonstrasi atau melalui bahan bacaan. }\end{array}$ \\
\hline Fase 3: & Menjelaskan kepada siswa cara membentuk \\
Mengorganisasikan siswa & kelompok belajar dan membantu setiap \\
ke dalam kelompok- & kelompok agar melakukan transisi secara \\
kelompok belajar. & efisien. \\
\hline $\begin{array}{l}\text { Fase 4: } \\
\text { Membimbing kelompok } \\
\text { bekerja dan belajar. }\end{array}$ & $\begin{array}{l}\text { Membimbing kelompok belajar pada saat } \\
\text { mereka mengerjakan tugas mereka. }\end{array}$ \\
\hline Fase 5: & $\begin{array}{l}\text { Mengevaluasi hasil belajar tentang materi yang } \\
\text { Evaluasi. }\end{array}$ \\
telah dipelajari/ meminta presentasi hasil kerja \\
kepada kelompok.
\end{tabular}




\begin{tabular}{ll}
\multicolumn{1}{c}{ Fase-fase } & \multicolumn{1}{c}{ Perilaku Guru } \\
\hline Fase 6: & Menghargai upaya dan hasil belajar individu dan \\
Memberikan penghargaan. & kelompok. \\
\hline
\end{tabular}

\section{Model Pembelajaran \\ Kooperatif Tipe Group Investigation (GI) \\ Slavin}

(2010:

menyatakan model pembelajaran kooperatif tipe GI merupakan salah satu tipe kooperatif yang menuntut siswa untuk memiliki kemampuan dalam berkomunikasi dan ketrampilan proses berkelompok. Komunikasi dan interaksi kooperatif di antara sesama teman sekelas akan mencapai hasil terbaik apabila dilakukan dalam kelompok kecil, di mana pertukaran di antara teman sekelas dan sikap-sikap kooperatif bisa terus bertahan. Aspek rasa sosial dari kelompok, pertukaran intelektualnya, dan maksud dari subjek yang berkaitan dengannya dapat bertindak sebagai sumbersumber penting maksud tersebut bagi usaha para siswa untuk belajar.

Nanang dan Cucu (2009: 48) menjelaskan langkah-langkah yang dapat dilakukan dalam model pembelajaran group investigation sebagai berikut:

a. Guru membagi kelas dalam beberapa kelompok heterogen.

b. Guru menjelaskan maksud pembelajaran dan tugas kelompok. c. Guru memanggil ketua dari masingmasing kelompok untuk mengambil satu materi tugas yang berbeda.

d. Masing-masing kelompok secara kooperatif membahas materi yang berisi materi temuan.

e. Setelah diskusi kelompok, juru bicara dari masing-masing kelompok menyampaikan hasil pembahasannya.

f. Guru memberikan penjelasan singkat sekaligus memberi kesimpulan.

g. Evaluasi.

h. Penutup.

5. Problematika Penerapan Model Pembelajaran Kooperatif Tipe Group Investigation (GI)

Jika group investigation merupakan model pembelajaran kooperatif, maka sintaks atau langkahlangkah dalam GI mengacu pada sintaks pembelajaran kooperatif yang telah dijelaskan sebelumnya. Namun, pada langkah-langkah GI di atas, masih ada langkah-langkah yang belum mengacu pada sintaks pembelajaran kooperatif sehingga menimbulkan beberapa masalah. Adapun masalah tersebut antara lain:

a. Pada langkah pertama disebutkan bahwa kelas dibagi menjadi beberapa kelompok heterogen. Disini akan muncul pertanyaan, berapa jumlah anak dalam masing-masing kelompok? Heterogen kelompok disini maksudnya heterogen yang 
bagaimana? Apakah hanya dengan heterogen dari segi jenis kelamin saja sudah cukup? Mengacu pada tujuan pembelajaran kooperatif dimana siswa bisa menerima terhadap keanekaragaman, maka pembagian kelompok heterogen ini harus adil untuk semua siswa.

b. Pada langkah ketiga, dijelaskan bahwa setiap kelompok mendapatkan materi yang berbeda. Jika nanti pada akhirnya setiap kelompok akan mempresentasikan hasil pembahasan kelompok, maka langkah ketiga ini akan menimbulkan masalah. Beberapa masalah tersebut antara lain:

- Dari segi materi, pada saat presentasi, ada kemungkinan kelompok lain tidak mengetahui materi yang disampaikan dalam presentasi tersebut sudah lengkap atau belum, sudah tepat semua atau ada yang masih kurang tepat.

- Dari segi efesiensi waktu, apabila setiap kelompok mendapatkan materi yang berbeda, otomatis semua kelompok perlu mempresentasikan hasil pembahasannya dan hal tersebut menghabiskan banyak waktu sehingga jam pelajaran banyak terbuat untuk presentasi kelompok.

c. Jika pada langkah keempat disebutkan untuk diskusi kelompok, maka ada kemungkinan hanya anggota kelompok yang pintar saja yang mau membahas dan mempelajari materi yang dibebankan pada kelompok, padahal pada sentral karakteristik pembelajaran kooperatif dikatakan keberhasilan suatu kelompok tergantung pada pembelajaran setiap anggota kelompok dalam memahami materi. Oleh karena itu perlu adanya pertanggungjawaban setiap anggota kelompok pada tugas yang mereka dapatkan.

d. Pada langkah kelima, ada juru bicara dari masing-masing kelompok yang akan mempresentasikan hasil pembahasan kelompok, namun belum disebutkan dengan jelas bagaimana pemilihan juru bicara ini. Apakah kelompok tersebut memilih juru bicara mereka sendiri atau guru menunjuk salah satu anggota kelompok untuk dijadikan juru bicara? Apabila tidak jelas seperti ini akan menimbulkan permasalahan, dimana setiap anggota kelompok akan saling tunjuk atau hanya akan memilih anggota kelompok yang dianggap pandai. Padahal dalam karakteristik pembelajaran kooperatif, setiap siswa mempunyai kesempatan yang sama untuk mencapai keberhasilan, lalu bagaimana dengan anak yang kurang pandai? Apakah mereka akan tetap statis seperti itu? 
e. Sebagian besar fakta dan pengalaman penulis, jika setiap kelompok hanya mempresentasikan materi yang mereka dapatkan, bukan mempresentasikan hasil diskusi pengerjaan soal kelompok, maka mereka hanya akan mengcopy paste materi yang ada di buku dan LKS. Jarang dari kelompok tersebut yang sungguh-sungguh

mempelajarinya, maka apakah hanya dengan presentasi kelompok, guru sudah dapat mengetahui seberapa besar kelompok tersebut menguasai materi yang mereka bahas? Apakah dengan presentasi saja, guru sudah bisa memberikan nilai untuk hasil kerja pada masing-masing kelompok?

f. Menurut Paul Suparno (1997: 65), dalam prinsip kontruktivis, seorang guru berperan sebagai mediator dan fasilitator yang membantu agar proses belajar murid berjalan dengan baik. Pada langkah keenam disebutkan guru memberi kesimpulan, apakah ini sudah sesuai dengan istilah yang menyatakan guru sebagai fasilitator?

g. Pada langkah GI di atas, belum ada langkah yang secara signifikan meningkatkan rasa kerjasama antar anggota kelompok. Jika hanya mengandalkan presentasi kelompok, maka sama seperti permasalahan yang telah disebutkan pada poin ke-3, 4, dan 5 di atas dimana ada kemungkinan hanya siswa yang dianggap pandai saja yang bekerja dalam kelompok. Oleh karena itu, diperlukan suatu langkah yang secara signifikan dapat mengingkatkan kerjasama antar anggota kelompok.

\section{Alternatif Solusi Problematika Penerapan Model Pembelajaran

Kooperatif Tipe Group
Investigation (GI)

Keberhasilan proses pembelajaran bisa didapatkan apabila permasalahanpermasalahan dalam proses tersebut bisa diminimalisasi. Berdasarkan permasalahan-permasalahan yang telah diungkapkan di atas, penulis mencoba memberikan alternatif solusi sebagai berikut:

a. Untuk mengatasi permalahan pada langkah pertama, guru sebaiknya membagi kelompok yang terdiri dari 2-4 siswa. Kenapa 2-4 siswa? Mengacu pada Permendiknas No.41 Tahun 2007, jumlah maksimal rombongan belajar pada SMP/MT adalah 32 peserta didik. Dari 32 siswa tersebut bisa adil dalam penempatan kelompok jika masing-masing kelompok berisi 2-4 siswa. Selain itu, dengan membentuk kelompok yang terdiri dari 2-4 bisa mengurangi kegaduhan di dalam kelas, karena pembentukan kelompok bisa dilakukan dengan teman sebangku atau teman pada bangku depan atau 
belakang. Untuk masalah heterogen, guru harus adil membagi kelompok baik berdasarkan jenis kelamin, tingkat kecerdasan, sosial, dll. Sebaiknya guru membagi kelompok berdasarkan nilai siswa, misalkan nilai ulangan harian. Jadi dalam satu kelompok tersebut ada laki-laki, ada perempuan, ada siswa yang mempunyai tingkat kecerdasarn tinggi, sedang, dan rendah. Berikut contoh pembagian kelompok ditinjau dari tingkat kecerdasannya:

\begin{tabular}{|c|c|c|c|c|c|c|c|c|}
\hline$\overline{\mathrm{TK}}$ & $\overline{\mathrm{PK}}$ & $\overline{\mathrm{Kel}}$ & $\overline{\mathrm{TK}}$ & $\overline{\mathrm{PK}}$ & $\overline{\mathrm{Kel}}$ & $\overline{\mathrm{TK}}$ & $\overline{\mathrm{PK}}$ & $\mathrm{Kel}$ \\
\hline \multirow{10}{*}{ Tinggi } & 1 & $\mathrm{~A}$ & \multirow{12}{*}{ Sedang } & 11 & $\mathrm{C}$ & \multirow{10}{*}{ Rendah } & 23 & $\mathrm{G}$ \\
\hline & 2 & B & & 12 & $\mathrm{D}$ & & 24 & $\overline{\mathrm{H}}$ \\
\hline & 3 & $\mathrm{C}$ & & 13 & $\mathrm{H}$ & & 25 & $\mathrm{H}$ \\
\hline & 4 & $\mathrm{D}$ & & 14 & $\mathrm{G}$ & & 26 & $\mathrm{G}$ \\
\hline & 5 & $\mathrm{E}$ & & 15 & $\mathrm{~F}$ & & 27 & $\mathrm{~F}$ \\
\hline & 6 & $\mathrm{~F}$ & & 16 & $E$ & & 28 & $E$ \\
\hline & 7 & $\mathrm{G}$ & & 17 & $\mathrm{~A}$ & & 29 & $\mathrm{D}$ \\
\hline & 8 & $\mathrm{H}$ & & 18 & $\mathrm{~B}$ & & 30 & $\mathrm{C}$ \\
\hline & 9 & A & & 19 & $\mathrm{C}$ & & 31 & B \\
\hline & 10 & $\mathrm{~B}$ & & 20 & $\mathrm{D}$ & & 32 & $\mathrm{~A}$ \\
\hline & & & & 21 & $\mathrm{E}$ & & & \\
\hline & & & & 22 & $\mathrm{~F}$ & & & \\
\hline
\end{tabular}

Ket: $\mathrm{TK}=$ Tingkat Kecerdasan; $\mathrm{PK}=$ Peringkat Kelas; $\mathrm{Kel}=$ Kelompok .

b. Alternatif solusi yang diberikan untuk permasalahan langkah ketiga adalah sebaiknya dua kelompok mendapatkan materi yang sama. Misalkan materi yang akan dibahas pada hari itu adalah bangun ruang sisi lengkung. Kelompok A dan B mendapatkan materi tugas tentang kubus, kelompok $\mathrm{C}$ dan $\mathrm{D}$ mendapatkan materi tugas tentang balok, dst. Sehingga dari alternatif solusi ini, keuntungan yang didapatkan adalah:
- Dari segi materi, jika hasil presentasi kelompok $\mathrm{A}$ ada yang kurang lengkap, maka kelompok B bisa melengkapi kekurangan tersebut, atau sebaliknya.

- Dari segi efesien waktu, jam pelajaran tidak habis hanya untuk presentasi, sehingga proses pembelajaran yang lain masih sempat dilaksanakan.

c. Mengenai permasalahan pada langkah keempat, sebaiknya setiap anggota kelompok mendapatkan tugas yang berbeda dalam mempelajari materi tugas yang diberi guru. Misalkan materi yang akan dibahas pada hari 
itu adalah bangun ruang sisi datar. Kelompok A mendapatkan materi tentang kubus. Karena satu kelompok terdiri dari 4 siswa, maka siswa I mempelajari tentang ciri-ciri kubus, siswa II mempelajari tentang jaring-jaring kubus, siswa III mempelajari tentang volume kubus, dan siswa IV mempelajari tentang luas permukaan kubus. Dengan demikian meminimalkan anggota kelompok yang hanya bergantung pada teman sekelompok yang pandai, dan juga mereka merasa mempunyai tanggung jawab secara individu dalam memahami materi.

d. Untuk menjawab permasalahan langkah kelima, maka perlu dijelaskan dengan rinci bagaimana pemilihan juru bicara kelompok. Dalam pemilihan ini ada dua cara, memilih sendiri atau dipilih oleh guru. Apabila kelompok memilih sendiri juru bicara mereka, maka ada kemungkinan: (1) Mereka hanya akan menunjuk anggota kelompok yang dianggap pintar saja, (2) Mereka menunjuk secara random anggota kelompok sehingga nantinya hanya anggota kelompok yang ditunjuk itulah yang akan siap dengan materi yang telah dibahas. Padahal menurut Samson (dalam Nanang dan
Cucu, 2009: 22), salah satu indikator tujuan belajar pada aspek psikomotorik adalah kesiapan siswa untuk diambil tindakan. Oleh karena itu, alangkah lebih baiknya jika juru bicara ditunjuk langsung oleh guru ketika kelompok tersebut akan mendapatkan giliran untuk presentasi, sehingga seluruh anggota kelompok siap dengan materi yang telah dibahas dengan tujuan mereka memahami materi yang mereka bahas.

e. Untuk mengatasi permasalahan poin keempat, maka perlu ditambahkan kegiatan evaluasi kelompok pada langkah-langkah GI. Kegiatan evaluasi kelompok ini bertujuan untuk mengukur perkembangan atau kemajuan akademik setiap anggota kelompok. Langkah ini dapat ditambahkan setelah langkah kelima. Jadi setelah langkah kelima, guru memberikan evaluasi kelompok untuk mengukur perkembangan atau kemajuan akademik setiap anggota kelompok.

f. Menjawab permasalahan pada langkah keenam, sebaiknya guru mengarahkan atau mendampingi siswa untuk membuat kesimpulan. Sehingga peran guru sebagai fasilitator dalam langkah ini terlaksana. Akibatnya, siswa juga bisa memenuhi salah satu indikator tujuan belajar pada aspek kognitif yaitu sintesis dimana siswa mempunyai kemampuan menyimpulkan, mempersatukan bagian yang terpisah guna membangun suatu keseluruhan, dan sebagainya. 
g. Untuk menjawab permasalahan poin ketujuh, maka perlu adanya langkah yang secara signifikan dapat mengingkatkan kerjasama antar anggota kelompok, misalkan dengan kuis terbuka antar kelompok dengan sistematika berikut:

- Anggota yang dianggap kurang pandai dijadikan sebagai juru jawab kelompok, maka secara otomatis anggota yang dianggap pandai akan mengajari anggota yang kurang pandai tersebut, sehingga mereka akan saling bekerjasama untuk mendapatkan hasil yang terbaik.

- Mengacu pada poin a di atas, pemilihan juru jawab ditentukan oleh guru, karena jika kelompok memilih sendiri maka anggota kelompok yang dianggap pintarlah yang akan dipilih menjadi juru jawab kelompok. Apabila hal ini terjadi, maka kerjasama tersebut tidak akan terjadi karena juru jawab sudah bisa memikirkan jawaban kuis itu sendiri.

Dengan demikian, berdasarkan alternatif solusi yang ditawarkan di atas, dapat meminimalkan kekurangankekurangan dalam GI dan melengkapi GI yang sudah ada menjadi model pembelajaran yang lebih efektif dalam meningkatkan prestasi belajar siswa. Adapun langkah-langkah GI yang termodifikasi sebagai berikut:

a. Guru membagi kelas dalam beberapa kelompok heterogen baik jenis kelamin, tingkat kecerdasan, sosial, dll, dengan masing-masing kelompok terdiri dari 2-4 siswa. Pembagian kelompok dapat didasarkan pada nilai hasil ulangan harian sebelumnya.

b. Guru menjelaskan maksud pembelajaran dan tugas kelompok.

c. Guru memanggil ketua dari masingmasing kelompok untuk mengambil satu materi tugas, dimana setiap dua kelompok akan mendapatkan materi yang sama.

d. Masing-masing anggota kelompok diberikan tugas yang berbeda dalam menginvestigasi sub materi kelompok.

e. Kelompok secara kooperatif membahas materi yang berisi materi temuan dari masing-masing anggota kelompok.

f. Setelah diskusi kelompok, juru bicara dari masing-masing kelompok menyampaikan hasil pembahasannya. Juru bicara tiap kelompok ditentukan oleh guru pada saat kelompok tersebut akan mendapat giliran untuk presentasi.

g. Evaluasi kelompok.

h. Guru memberikan klarifikasi singkat tentang materi yang telah diinvestigasi oleh masing-masing kelompok.

i. Guru mendampingi atau membimbing siswa membuat kesimpulan. 
j. Kuis terbuka antar kelompok.

$\mathrm{k}$. Evaluasi individu.

1. Penutup.

\section{Penutup}

Berdasarkan ulasan-ulasan pada bab sebelumnya, kesimpulan dari penulisan makalah ini adalah:

1. Problematika apa yang terjadi pada penerapan model pembelajaran kooperatif tipe Group Investigation (GI) sebagai berikut:

a. Pada langkah pertama, kelas dibagi menjadi beberapa kelompok heterogen. Disini akan muncul pertanyaan, berapa jumlah anak dalam masing-masing kelompok? Heterogen kelompok disini maksudnya heterogen yag bagaimana?

b. Pada langkah ketiga, jika setiap kelompok mendapatkan materi yang berbeda, maka akan menimbulkan masalah antara lain: 1) Dari segi materi, pada saat presentasi, ada kemungkinan kelompok lain tidak mengetahui materi yang disampaikan dalam presentasi tersebut sudah lengkap atau belum, sudah tepat semua atau ada yang masih kurang tepat, 2) Dari segi efesiensi waktu, apabila setiap kelompok mendapatkan materi yang berbeda, otomatis semua kelompok perlu mempresentasikan hasil pembahasannya dan hal tersebut menghabiskan banyak waktu sehingga jam pelajaran banyak terbuat untuk presentasi kelompok.

c. Pada langkah keempat, terdapat diskusi kelompok. Permasalahan yang muncul adalah kemungkinan hanya anggota kelompok yang pintar saja yang mau membahas dan mempelajari materi yang dibebankan pada kelompok. Lalu bagaimana dengan pertanggungjawaban masingmasing anggota kelompok terhadap materi yang dibebankan untuk dipelajari?

d. Pada langkah kelima, permasalahan yang muncul adalah belum disebutkannya dengan jelas bagaimana pemilihan juru bicara pada masing-masing kelompok.

e. Belum adanya langkah evaluasi kelompok dimana evaluasi ini bertujuan untuk mengukur perkembangan atau kemajuan akademik setiap anggota kelompok.

f. Pada langkah keenam, jika guru memberikan kesimpulan, apakah peran guru sebagai fasilitator terpenuhi?

g. Pada langkah GI, belum ada langkah yang secara signifikan meningkatkan rasa kerjasama antar anggota kelompok.

2. Alternatif solusi hasil diagnosis dari problematika penerapan model pembelajaran kooperatif tipe Group 
Investigation (GI) adalah dengan memodifikasi model pembelajaran kooperatif tipe GI. Berikut penjabaran langkahlangkah GI yang termodifikasi:

a. Guru membagi kelas dalam beberapa kelompok heterogen baik jenis kelamin, tingkat kecerdasan, sosial, dll, dengan masing-masing kelompok terdiri dari 2-4 siswa. Pembagian kelompok dapat didasarkan pada nilai hasil ulangan harian sebelumnya.

b. Guru menjelaskan maksud pembelajaran dan tugas kelompok.

c. Guru memanggil ketua dari masing-masing kelompok untuk mengambil satu materi tugas, dimana setiap dua kelompok akan mendapatkan materi yang sama.

d. Masing-masing anggota kelompok diberikan tugas yang berbeda dalam menginvestigasi sub materi kelompok.

e. Kelompok secara kooperatif membahas materi yang berisi materi temuan dari masingmasing anggota kelompok.

f. Setelah diskusi kelompok, juru bicara dari masingmasing kelompok menyampaikan hasil pembahasannya. Juru bicara tiap kelompok ditentukan oleh guru pada saat kelompok tersebut akan mendapat giliran untuk presentasi.

g. Evaluasi kelompok.

h. Guru memberikan klarifikasi singkat tentang materi yang telah diinvestigasi oleh masing-masing kelompok.

i. Guru mendampingi atau membimbing siswa membuat kesimpulan.

j. Kuis terbuka antar kelompok.

k. Evaluasi individu.

1. Penutup

\section{Daftar Rujukan}

Agus Suprijono. 2009. Cooperative Learning: Teori dan Aplikasi PAIKEM, Yogyakrta: Pustaka Pelajar.

Anita Lie. 2005. Cooperative Learning : Mempraktikan Cooperative Learning di Ruang-ruang Kelas. Jakarta: PT Grasindo.

Hamdani. 2011. Strategi Belajar Mengajar. Bandung: Pustaka Setia.

Nanang dan Cucu. 2009. Konsep Strategi Pembelajaran. Bandung: PT Refika Aditama.

Paul Suparno. 1997. Filsafat Konstruktivisme dalam Pemdidikan. Yogyakarta: Kanisius

Permendiknas No.41 Tahun 2007 tentang Standar Proses Untuk Satuan Pendidikan Dasan dan Menengah. 
222 | Premiere Educandum, Volume 5 Nomor 2, Desember 2015, 210 - 222

Rusman. 2012. Model-Model

Pembelajaran:

Mengembangkan

Profesionalisme Guru.

Jakarta: PT Raja Grafindo

Persada.

Slavin. 2010. Cooperative Learning: Teori, Riset, dan Praktik. Bandung: Nusa Media

UU No.20 tahun 2003 tentang Sistem Pendidikan Nasional 